\title{
Romuald Grzybowski, Wyższe szkoły pedagogiczne w Polsce w latach 1946-1956, Akademia Wychowania Fizycznego im. Jędrzeja Sniadeckiego w Gdańsku, Gdańsk 2000, ss. 426
}

Zainteresowania naukowe Romualda Grzybowskiego dziedziną historii oświaty i wychowania datują się od czasu studiów w Uniwersytecie Gdańskim (1975 - 1979), gdy zapisał się na seminarium magisterskie $\mathrm{z}$ tego zakresu, a następnie przygotował $i$ obronił pracę magisterską na temat: „Problem oświaty wsi na łamach «Gazety Grudziądzkiej»".

W dwudziestoleciu 1980-2000 zainteresowania R. Grzybowskiego objęły trzy główne problemy badawcze:

- historyczne przemiany ideałów wychowania na przestrzeni dziejów;

- kształcenie nauczycieli na poziomie średnim i półwyższym w województwie gdańskim po 1945 roku;

- dzieje szkół wyższych w Polsce po drugiej wojnie światowej, ze szczególnym uwzględnieniem uczelni kształcących nauczycieli.

Znaczącym etapem w badaniach był okres 1981 - 1987, gdy R. Grzybowski przygotował pod kierunkiem prof. zw. dr hab. Lecha Mokrzeckiego dysertację doktorską na temat: „Problematyka kształcenia nauczycieli na poziomie średnim w województwie gdańskim w latach 1945-1975". To wówczas poznał i opanował tajniki metodologii badań historycznych, co pozwoliło w nasteppnych kilkunastu latach opublikować szereg artykulów ze wspomnianych trzech kierunków badań oraz wydać drukiem pod wspólną redakcją z M. Krasnopolskim i Z. Pawluczukiem w 1999 r. pracę pt. „Humanistyczny wymiar edukacji nauczycieli wychowania fizycznego" (Gdańsk 1999) i dwie calkowicie samodzielnie: „Studia nauczycielskie w województwie gdańskim w latach 1955-1970. Ich rozwój i efekty kształcenia" (Gdańsk 1994, ss. 115) i „Wyższe szkoły pedagogiczne w Polsce w latach 1946-1956" (Gdańsk 2000, ss. 426).

Recenzując najnowsza prace dotycząca WSP w Polsce w latach 1946-1956 warto podkreślić bogatą i staranną kwerendę zarówno źródeł archiwalnych, jak i literatury, której Autor dokonal w ciagu kilkunastu lat badań po doktoracie. Kwerenda objęła: staż w Krakowie (1983), penetrację zasobów archiwalnych Archiwum Akt Nowych w Warszawie (zespoły: Ministerstwa Oświaty, Ministerstwa Szkolnictwa Wyższego, Komitetu Centralnego PZPR, Zarządu Głównego ZNP); Archiwum Związku Nauczycielstwa Polskiego w Warszawie (akta Wydziału Nauki i Wydziału Pedagogicznego, Sekcji Zakładów Kształcenia); Archiwum Państwowego w Gdańsku (akta WSP w Gdańsku); Archiwum Uniwersytetu Warszawskiego (akta WSP w Warszawie); Archiwum Uniwersytetu Gdańskiego (akta WSP w Gdańsku).

Krytycznie Autor odniósł się do wszelkich źródeł drukowanych, w tym przepisów opublikowanych w Dziennikach Ustaw, Dzienniku Urzędowym Ministerstwa Oświaty i Ministerstwa Szkolnictwa Wyższego, prográmów studiów, statutów organizacji studenckich, statystyk szkolnictwa lat 1945-1956, instrukcji KC PZPR.

Po przestudiowaniu ponad 500 pozycji literatury $i$ wspomnianych archiwaliów R. Grzybowski przed ostateczną redakcją pracy wyniki dotychczasowych badań zaprezentował w formie referatu lub głosu w dyskusji w najbardziej liczących się ośrodkach naukowych w kraju: Warszawie, Krakowie, Poznaniu, Gdańsku i Bydgoszczy. Takie podejście pozwoliło uniknąć błędów, ale też i wyświetlić szereg niejasności i "białych plam".

Omawiając treść pracy należy wyraźnie zaznaczyć, iż Autor przejrzyście zarysowal zarówno funkcję założonz̧ jak i rzeczywistą WSP w Polsce w latach 1946-1956 na tle ogólnej sytuacji oświaty, potrzeb kadrowych szkolnictwa podstawowego i średniego, programów i decyzji wladz politycznych (KC PZPR) oraz resortu oświaty i szkolnictwa wyższego. 
Na konstrukcję pracy składają się: wstęp (ss. 16), siedem rozdziałów, zakończenie, bibliografia, 40 tabel oraz niezwykle bogate przypisy.

W I rozdziale „Okoliczności powstania oraz rozwój organizacyjny wyższych szkół pedagogicznych w latach 1946-1949" (ss. 48) omówiono stan zniszczeń wojennych, sytuacje kadrową szkolnictwa, odbudowę sieci pedagogiów działających do 1946 r., powstanie na ich bazie WSP jako placówek kształcących nauczycieli dla potrzeb szkół średnich.

W kolejnym rozdziale ukazano rozwój organizacyjny placówek w czasie planu 6-letniego, zmiany organizacyjno-programowe, bedące konsekwencja wprowadzenia statutu w 1953 roku oraz zreformowanie studiów zawodowych na rzecz magisterskich. W rozdziale „Wyższe szkoły pedagogiczne w latach "1949-1956. Nadzieje i zagrożenia" (ss. 49) R. Grzybowski na s. 108 - 120 wymienil najbardziej znaczące zagrożenia dla istnienia tych placówek. Są to między innymi: „groźba nadprodukcji" nauczycieli $z$ wyższym wykształceniem $z$ uwagi na zbliżający się niż demograficzny w szkołach, rozbudowa szkolnictwa zawodowego kosztem ograniczeń szkolnictwa ogólnokształcącego, zarzut zbędnej dwutorowości ksztakcenia nauczycieli w miastach uniwersyteckich.

Niezwykle rzeczowo przedstawil Autor problem kadr nauczycielskich (s. 121 - 206), cała ówczesną strategię "doboru" kadr, szeroka ofensywę ideologiczną czynników partyjnych i władz resortu zakoniczona „czystka" we wszystkich kategoriach pracowników, w tym i we wladzach poszczególnych uczelni. Cytowane przez Autora dokumenty ujawniaja proces „upartyjnienia” nauczycieli droga ,ideologicznego szkolenia" oraz stosowania „rygorów socjalistycznej dyscypliny pracy". Wspomniane praktyki pozwolity na zwalnianie bądź odsuwanie od pracy dydaktycznej ze studentami nauczycieli „światopoglądowo niepewnych" oraz blokowanie ich dalszego awansu naukowego. Opisane przez R. Grzybowskiego liczne przykłady takich praktyk byly „zgodne" $z$ ówczesnymi przepisami dotyczącymi awansu pracowników nauki.

Tabele 15,16 i 17 oraz wniosek zamieszczony na s. 191-192 świadczą dobitnie iż
„Ostateczne rezultaty polityki kadrowej, realizowanej w stosunku do WSP w latach 1949-1956 ... nie były satysfakcjonujące. (...) Wyższe szkoły pedagogiczne wyróżniały się niskim odsetkiem samodzielnych etatowych pracowników nauki".

W rozdziale „Materialne podstawy rozwoju WSP" (s. 207-235) dokonano charakterystyki bazy lokalowej poszczególnych placówek. W tej sferze większość $\mathrm{z}$ nich (poza Warszawa i Krakowem) przez cały okres czasu odczuwała brak odpowiednich pomieszczeń do dydaktyki, środków na budowę nowych obiektów, na kapitalne remonty $i$ adaptację. Był to rezultat „oszczędności w dziedzinie budownictwa” (s. 211), które dotkliwie zaznaczyły się poza dydaktyką również $w$ bazie bibliotecznej oraz socjalnej studentów.

Szeroko omawia Autor działalność dydaktyczną WSP (s. 237 - 306) w rozdziale piątym. Obejmuje on analizę planów studiów, ewaluację programów przedmiotów, pedagogicznych praktyk, przebieg i efekty kształcenia, odpad i odsiew w latach 1950 - 1956, pracę kół naukowych, egzaminy dyplomowe i magisterskie na studiach stacjonarnych i zaocznych.

Osobno w VI rozdziale pt. „Działalność wychowawcza WSP" (s. 307-340) ujęto statutowe cele $\mathrm{i}$ ideały wychowawcze uczelni $\mathrm{i}$ organizacji młodzieżowych w dwóch etapach czasowych: 1946 - 1948 i po 1948 roku. Szczególnie precyzyjnie ukazano okres likwidacji pluralizmu organizacji studenckich (s. 314-322) oraz prymat Związku Młodzieży Polskiej w „nasycaniu wykładów i ćwiczeń problematyką ideologiczną" (s. 231 i nast), w organizacji obchodów świąt państwowych oraz w działalności kulturalno-oświatowej studentów.

W końcowej części pracy („Studenci i absolwenci WSP" s. 341-386) R. Grzybowski ukazał zasady naboru i przebieg rekrutacji kandydatów na studia, ich pochodzenie społeczne, ocenę ilościową $\mathrm{i}$ jakościową absolwentów, praktykę „odgórnie ustalanych limitów przyjęć dla kandydatów z poszczególnych klas społecznych" oraz rodzaje pomocy materialnej udzielanej studentom.

Dokonując oceny przygotowania zawodowego absolwentów Autor stwierdził: „Praktyka pierwszej połowy lat pięćdziesiątych wykazała, 
że w systemie 3-letnich studiów zawodowych nie można [było] należycie wykształcić nauczyciela szkoły średniej: ani w wyższej szkole pedagogicznej, ani w uniwersytecie". Stąd późniejsze decyzje o czteroletnim cyklu studiów po 1954 r.

W „Zakończeniu" (s. 387 - 392) syntetycznie Autor ukazał trudną drogę, jaka przebyły WSP, ich osiągnięcia i efekty które należy mierzyć „nie tylko liczbą absolwentów, ale też ich wkładem w rozwój kulturalny i naukowy regionów i miast, w których funkcjonowały" (s. 391).
Dokonując oceny merytorycznej pracy R. Grzybowskiego z cała powag̨ można stwierdzić, iż wypehia ona w sposób niezwykle istotny dotychczasową lukę w badaniach nad problematyką kształcenia nauczycieli dla szkół średnich w Polsce. Dodać wypada, iż jej ukazanie się w roku 2000 znakomicie może sie przydać „reformatorom" oświaty oraz studentom kierunków nauczycielskich, którzy będą ją zmieniać w XXI wieku.

\section{Immanuel Kant, O pedagogice, thumaczenie Dorota Sxtobryn, slowo wstępne, Slawomir Sztobryn, Lódź 1999, Wydawnictwo Dajas, ss. 105}

Polska myśl edukacyjna dowodzi, iż na przestrzeni dziejów jej rozwoju lączyła w sobie zarówno wątki rodzime, jak i obce. Śledząc recepcję europejskiej, czy światowej myśli pedagogicznej na gruncie polskim zauważa się, iż przybierała ona różne formy i występowała w mniejszym lub większym nasileniu. Była nie tylko wyrazem intelektualnej refleksji na pojawiające się nowe idee w obszarze pedagogicznym, lecz także wyrazem potrzeb polskiej teorii i praktyki edukacyjnej. Jest wiele nazwisk, które na trwale zapisały się w polskiej historiografii pedagogicznej, żeby wymienić F. Froebla, J. F. Herbarta, J. A. Komeńskiego, J. H. Pestalozziego, czy wreszcie J. J. Rousseau. Te nazwiska znane są powszechnie polskiemu czytelnikowi. Niektóre idee $\mathrm{i}$ ich twórcy przeniesione zostały na grunt polski dzięki wąskiej grupie specjalistów. To stwierdzenie możemy odnieść do recenzowanej pracy.

I. Kant znany był i jest w polskiej nauce jako filozof. Gdyż o ile o filozofii I. Kanta można powiedzieć, iż miała w Polsce liczne grono zwolenników, interpretatorów, a także przeciwników, o tyle jego idee filozofii wychowania były mniej znane.

Wykłady o tematyce pedagogicznej I. Kant wygłaszał czterokrotnie, poczawszy od semestru zimowego $1776 / 7$, przez 1780, 1783/4 i $1786 / 7$, pozostały one jednak do 1803 roku w rekopisach. Dopiero w tym roku D. Friedrich i Th. Rink wydają „Über Pādagogik”. $Z$ kolei pierwszy polski przekład Jana Borowskiego ukazał się w Wilnie w 1819 roku. Dzisiaj po dokładnie 180 latach otrzymujemy nowe thumaczenie. Należy więc zapytać, jaka jest pedagogika Kanta skoro wzbudza i dzisiaj zainteresowanie? Pedagogika ta powstala $\mathrm{z}, \mathrm{a}-$ kademickiej konieczności” i obowiązku wykładowcy. Otóż, trzeba mieć świadomość, iż Kant nie stworzył systemu pedagogicznego, to kłóciłoby się z zasadami filozofii krytycznej. Można zrozumieć rozterki Kanta, który zostaje wytypowany do wygłoszenia kursowego wykładu z pedagogiki.

Wykłady o tematyce pedagogicznej wygłaszał Kant dokładnie wtedy, gdy rodziła się jego nowa filozofia, filozofia krytyczna. Warto w tym miejscu przypomnieć, iż Krytyka czystego rozumu opublikowana zostaje w roku 1781. Gdy zatem rozpoczynał Kant swoje wykłady pedagogiczne po raz pierwszy (1776/7) jest już „rewolucjonista" na polu filozofii, gdy czyni to po raz drugi (1780) jego Krytyka... jest już w druku. Stojąc na gruncie filozofii krytycznej wie, że zadaniem filozofa jest pytanie o „warunki, możliwości"? Lecz wykład o pedagogice 